\title{
RELATION BETWEEN WORKING MEMORY AND SELF-CONTROL CAPACITY IN PARTICIPANTS WITH MILD INTELLECTUAL DISABILITY?
}

\author{
Bojan DUČIĆ 2 \\ University of Belgrade \\ Faculty of Special Education and Rehabilitation
}

Working memory is activated in situations which require active control of directing attention, processing information and making it available for a short time. Its content is limited in capacity and changes with regard to the context of a performed activity. Self-control is the capacity of a voluntary conscious effort to persist in achieving a previously set goal.

The aim of this research was to determine the relation of verbal and visuospatial aspects of working memory with self-control skills in persons with mild intellectual disability (ID).

The sample included 40 participants $8-12$ years of age $(M=10.65$, $S D=1.19)$. Memorizing a Maze task, adapted for participants with $I D$, was used to determine the capacity of visuospatial aspect of working memory. Memorizing Animals task was used to assess verbal aspect of working memory, and Self-Control Rating Scale was used to determine the acquisition level of self-control skills.

It was determined that verbal aspects of working memory were significantly related to the acquired level of self-control skills $(p=0.002)$.

1 This paper is the result of the research project "Creating a protocol for assessing educational potentials of children with disabilities, as a criterion for the development of individual educational programs", ON 179025 (2011-2015), financed by the Ministry of Education, Science and Technological Development of the Republic of Serbia.

2 E-mail: bojanducic@yahoo.com 
Specijalna edukacija i rehabilitacija (Beograd), Vol. 16, br. 1. 55-72, 2017.

There was no significant relation between the results of tasks assessing the capacity of visuospatial working memory and the success on the scale assessing self-control capacity $(p=0.089)$.

The relation between self-control and verbal aspect of working memory may be explained by close links between using speech and applying self-regulation strategies.

Key words: working memory, self-control, intellectual disability

\section{INTRODUCTION}

Working memory capacity is activated when the information significant for performing a task needs to be available. The content of working memory changes with regard to needs for information relevant to a task which is at that moment the focus of a person's attention. Keeping necessary information simultaneously involves inhibiting distracters which may lead to an inadequate response (Engle, 2002). Working memory, as opposed to short-term memory, includes control mechanisms of directing, transferring, and dividing attention, i.e. executive attention. Apart from keeping information which is relevant to the context of a performed activity, working memory capacity also processes information which is significant for organizing thoughts and behavior at that moment (Baddeley, 2012).

By applying tasks which activate visuospatial and verbal aspects of working memory, it has been determined that they have a common basis, the so called central executive component, whose capacity influences the achievements on both types of tasks. As opposed to working memory, when assessing visuospatial and verbal capacity of short-term memory, the results were significantly different in both domains (Alloway, Gathercole \& Pickering, 2006; Kane et al., 2004).

Working memory is related to Spearman's g factor of intelligence, but cannot be reduced to general reasoning ability (Conway, Kane \& Engle, 2003).

Developmental level of working memory has an influence on dealing with everyday situations. People who 
have difficulties in remembering significant information necessary for solving a task, and who have difficulties in inhibiting irrelevant information, are less successful in solving mathematical problems (Pasolunghi, Cornoldi \& De Liberto, 1999). Numerous studies have shown that general academic success (Kaljača \& Dučić, 2016) and success in acquiring reading skills (Gathercole, Alloway, Willis \& Adams, 2006) and knowledge in mathematics (Friso-van den Bos, van der Ven, Kroesbergen \& van Luit, 2013) is related to the developmental level of self-control capacity.

It is assumed that the influence of negative social stereotypes leads to poorer success in tasks related to person's abilities which are included in the stereotype. Stigmatization of persons with ID has a negative influence on realizing life habits of persons who belong to this population (Dagnan \& Waring, 2004). One of the mechanisms of this influence is explained by reducing working memory capacity. When participants are told, prior to performing a task, that they are expected to be less successful according to a stereotypical belief, it burdens the capacity of working memory. Control mechanisms of working memory responsible for directing attention to the task are weakened by the attempt to inhibit negative thoughts and feelings, which reduces the ability to control evoking, keeping and processing relevant information (Schmader \& Johns, 2003).

Persons with intellectual disability (ID) have deficits in working memory and self-control. The lower the level of intellectual functioning, the more pronounced are difficulties and limitations in the development of working memory capacity (Schuchardt, Gebhardt \& Mäehler, 2010) and selfcontrol (Kaljača \& Dučić, 2016). It was determined that verbal IQ score of participants with mild ID positively correlated with the success in tasks assessing verbal working memory capacity (Buha \& Gligorović, 2012). Furthermore, deficits in working memory, especially in visuospatial aspect of working memory, were also noted in participants who were at the borderline of intellectual functioning (Alloway, 2010). The relation of working memory, i.e. executive attention, and inhibiting 
automatic reactions with self-regulation of behavior related to nutrition was found in typically developing population (Hofmann, Friese \& Roefs, 2009). However, by reviewing available literature, it was determined that there were not enough studies which analyzed the relation between working memory and self-control in participants with ID.

This research was conducted with the aim to determine the relation of verbal and visuospatial aspects of working memory with the acquired level of self-control skills in persons with mild ID.

\title{
METHOD
}

The sample consisted of 40 participants 8-12 years of age $(\mathrm{M}=10.65, \mathrm{SD}=1.19)$. The sample included $24(60 \%)$ boys and 16 (40\%) girls. All participants functioned at the level of mild ID. The participants' IQ ranged from 50 to 70 . Selection criterion in forming the sample was absence of motor, sensory, physical, and psychiatric disorders.

\section{Instruments}

\begin{abstract}
Assessment of visuospatial working memory. Memorizing a Maze task (Pickering, 2006), modified for participants with ID, was used to determine the developmental level of visuospatial working memory capacity. In the first part of the task, a participant was given a two-dimensional maze on an A4 sheet of paper. A red line marked a path within the maze. The participant was asked to trace with his/her finger over the red line twice. At the end of the first part of the task, the examiner took the paper with the red line away.

In the second part of the task, the examiner showed the participant an identical maze as in the first part, only without the marked path. The participant was expected to use a pencil and mark the position of the red line he/she saw in the first part
\end{abstract}


of the task. The same procedure was repeated six times using paths of increasing complexity. One point is awarded for each correct answer. The maximum score on the task is 6 points.

Assessment of verbal working memory. Memorizing Animals task was designed for this research as a task adapted to persons with ID, and was used to assess the developmental level of working memory capacity. The task is applicable only if a person with ID differentiates between the categories of objects and living beings. In order to check whether the participants differentiated between living beings and objects, each participant was given an example for an animal (dog) and an object (shoe) before the task. Following the examples presented by the examiner, the participants stated three animals and three objects on their own.

The examiner read a list with alternate names of animals and objects. A participant was instructed to memorize only animals, because the examiner would ask him/her to remember all the mentioned animals after reading the list. When the instructions were clear to the participant, the examiner read the list with objects and animals (television, cow, pillow, rabbit, house, bear, bus, mouse, chicken, glass) at a pace of one word every three seconds.

Three minutes after the participant's last attempt to remember the name of an animal read by the examiner, the participant was informed that the examiner would read another list with names of objects and animals, and that he/ she should memorize only the names of animals again. Then, the examiner read one word from the list every three seconds (lion, hat, sheep, ball, chair, wolf, soap, turtle, bag, monkey, plate, snake, pencil, pig, window, fox, telephone, elephant, and fish). After the last word was read, the participant was to repeat the names of animals he/she memorized. It was not necessary for a participant to repeat the words in the same order they were read in order to be successful in this task.

Memorizing Animals task was used for working memory assessment because it requires information processing along 
with memorizing. Performing this task means classifying information into an appropriate category and memorizing only the information from the target category while inhibiting the influence of the distracter category.

Correct answers from the first and second part were added up. The maximum number of correct answers is 15 . Apart from correct answers, the number of errors was also noted. Stating animals which were not on the list, or objects regardless of whether they were on the list or added by a participant, was considered an error.

Assessment of self-control. The developmental level of self-control capacity was assessed by Self-Control Rating Scale (SCRS, Kendall \& Wilcox, 1979). This scale includes behaviors which involve a high level of self-regulation, such as following rules, persistence, and inhibition of inappropriate behaviors. A person who provided information on participants' behavior gave answers on a seven point scale for 33 items. For each claim, the informant could choose one from the given answers: 1 - completely true, 2 - true, 3 - mostly true, 4 - both true and false, 5 - mostly false, 6 - false and 7 - completely false. After recoding, the total score was obtained by adding up answers on all items. The maximum number of points is 231, and a higher number indicate better developed self-control capacities. A satisfactory level of internal Self-Control Rating Scale consistency (Cronbach's $\alpha=0.97$ ) was determined in our sample. The authors of the Scale also recommended using this instrument on the basis of high values of internal consistency (Cronbach's $\alpha=0.98)$ and test-retest reliability ( $\mathrm{r}=0.84$ ) (Kendall \& Wilcox, 1979).

\section{Research procedure}

The research was conducted from 2013 to 2016 in four elementary schools: elementary school "Anton Skala", elementary school "Boško Buha", elementary school "Sava Jovanović Sirogojno", and elementary school "Novi Beograd". 
Students' parents were familiar with the aim of the research and were asked to give a written consent for their child to be included in the sample of this study. Data on possible comorbid disorders and the level of intellectual disability of students included in the sample were collected from school documentation. Adaptive Behavior Assessment System II scale (Harrison \& Oakland, 2003) was completed by special educators with the minimum of one year experience in working with the student for whom they provided information, while the instructions for working memory assessment tasks, which the participants performed individually, were presented by one of the research authors.

\section{Data processing}

Basic values of the obtained results were presented by methods of descriptive statistics: central tendency measures, variability measures, and the range between minimum and maximum achievement. Pearson's coefficient was used to determine correlation, and single factor Analysis of variance (ANOVA) was used to determine the relation between independent and dependent variables. Analysis of covariance (ANCOVA) was used to determine the relation between independent and dependent variables with statistical control of covariate influence.

Results

On the Self-Control Rating Scale, the participant who had 57 points was the one with the poorest achievement, while the participant with 212 points was the most successful $(\mathrm{M}=154.38, \mathrm{SD}=40.45)$.

Three participants had only one correct answer, while 16 participants answered correctly to all six items of the task which assessed visuospatial aspect of working memory $(\mathrm{M}=4.80$, 
Specijalna edukacija i rehabilitacija (Beograd), Vol. 16, br. 1. 55-72, 2017.

$\mathrm{SD}=1.49$ ). Achievement in the task assessing visuospatial aspect of working memory is presented in detail in Table 1.

Table 1 - Achievement in the task assessing visuospatial aspect of working memory

\begin{tabular}{ccc}
\hline \multirow{2}{*}{$\mathrm{N}$} & \multicolumn{2}{c}{ Correct answers } \\
\cline { 2 - 3 } & $\mathrm{N}$ & $\%$ \\
\hline 3 & 1 & 7.5 \\
\hline 1 & 2 & 2.5 \\
\hline 3 & 3 & 7.5 \\
\hline 3 & 4 & 7.5 \\
\hline 14 & 5 & 35.0 \\
\hline 16 & 6 & 40.0 \\
\hline
\end{tabular}

With regard to the obtained results in the task which assessed visuospatial aspect of working memory, by means of Visual Binning technique for the two given categories, the sample was divided into a group of successful participants, i.e. participants with maximum scores $(\mathrm{N}=16)$, and a group of less successful participants $(\mathrm{N}=24)$ which included the participants who did not give all correct answers. Achievements of these two groups of participants were compared on the Self-Control Rating Scale. It was determined that there were no significant differences in favor of the successful participants $(M=167.69$, $\mathrm{SD}=37.60)$ compared to the group of less successful participants $(\mathrm{M}=145.50, \mathrm{SD}=40.59),\left[\mathrm{F}(1,38)=3.039, \mathrm{p}=0.089, \eta^{2}=0.074\right]$.

In the task which assessed verbal aspect of working memory $(M=6,58, S D=2,77)$, two participants did not give a single correct answer. Three most successful participants had 11 correct answers each. None of the participants achieved the maximum score of 15 points. Only one participant (2.5\%) had six errors, while 23 (57.5\%) did not make a single mistake. Results of the task assessing verbal aspect of working memory are presented in detail in Table 2. 
Dučić, B.: Relation between working memory and self-control capacity in participants with mild intellectual disability

Table 2 - Achievement in the task assessing verbal aspect of working memory

\begin{tabular}{ccc}
\hline \multirow{2}{*}{$N$} & \multicolumn{2}{c}{ Correct answers } \\
\cline { 2 - 3 } & $\mathrm{N}$ & $\%$ \\
\hline 2 & 0 & 5.0 \\
\hline 2 & 2 & 5.0 \\
\hline 1 & 3 & 2.5 \\
\hline 4 & 4 & 10.0 \\
\hline 1 & 5 & 2.5 \\
\hline 10 & 6 & 25.0 \\
\hline 3 & 7 & 7.5 \\
\hline 7 & 8 & 17.5 \\
\hline 5 & 9 & 12.5 \\
\hline 2 & 10 & 5.0 \\
\hline 3 & 11 & 7.5 \\
\hline
\end{tabular}

Two groups were also formed with regard to achievement on the task which assessed verbal aspect of working memory. A group of less successful participants included 20 participants with six or fewer correct answers, while the group of successful participants included 20 participants with seven or more correct answers.

On the basis of Pearson's correlation coefficient, it was determined that there was a moderately positive and significant correlation between the results of tasks assessing verbal and visuospatial aspect of working memory $(\mathrm{r}=0.488, \mathrm{p}=0.001)$.

By comparing the results of working memory assessment and the results on the Self-Control Rating Scale, with controlling the influence of the number of made mistakes, it was determined that successful participants had significantly better results on the Self-Control Rating Scale than the less successful group. The results of comparing two groups of participants on the Self-Control Rating Scale are presented in detail in Table 3. 
Specijalna edukacija i rehabilitacija (Beograd), Vol. 16, br. 1. 55-72, 2017.

Table 3 - Results of less successful and successful participants on the Self-Control Rating Scale in the task assessing verbal aspect of working memory

\begin{tabular}{|c|c|c|c|c|c|c|}
\hline & \multicolumn{2}{|c|}{ Observed M } & Adjusted M & SD & & $\mathrm{n}$ \\
\hline $\begin{array}{l}\text { less successful } \\
\text { participants }\end{array}$ & \multicolumn{2}{|l|}{130.10} & 136.18 & 36.16 & & 20 \\
\hline \multirow[t]{2}{*}{$\begin{array}{l}\text { successful } \\
\text { participants }\end{array}$} & \multicolumn{2}{|l|}{178.65} & 172.58 & 28.47 & & 20 \\
\hline & SS & df & MS & $\mathrm{F}$ & $\mathrm{p}$ & Part. $\eta 2$ \\
\hline $\begin{array}{l}\text { participant's } \\
\text { errors }\end{array}$ & 5302.900 & 1 & 5302.900 & 5.616 & 0.023 & 0.132 \\
\hline group & 10363.59 & 1 & 10363.59 & 10.975 & 0.002 & 0.229 \\
\hline error & 34937.45 & 37 & 944.26 & & & \\
\hline
\end{tabular}

$\mathrm{R}^{2}=0.452 ;$ Adj. $\mathrm{R}^{2}=0.423$; adjustment was based on the mean value of Errors variable $=$ 0.90 . Homogeneity of regression slopes was tested and not significant: $F=1.102 ; p>0.05$. Regression coefficient of Errors variable was $-9.347,(p=3.944)$. Statistically significant variables are marked in bold.

SS - sum of squares; MS - mean square; Significant values are marked (bold).

\section{DISCUSSION}

This research was conducted with the aim to determine whether the developmental levels of visuospatial and verbal capacity of working memory were related to self-control skills of the participants with mild ID. It was determined that only the development of verbal aspect of working memory was significantly related to the achievement on Self-Control Rating Scale. Verbal working memory was assessed by a task with a much wider range of results, and thus none of the participants achieved maximum score in this task. On the other hand, 16 participants achieved maximum score in the task assessing visuospatial aspects of working memory. It is possible that due to "the ceiling effect", reduced variability of the results in this task contributed to the lack of evidence of the relation between visuospatial aspect of working memory and self-control. We assume that selection criterion according to which these two groups were formed might have influenced the absence of significant differences in the acquisition level of self-control skills between the participants who were successful and those 
who were partially successful in the task which assessed visuospatial working memory. It is possible that the participants who had 5 correct answers were closer to the achievements of the participants with maximum score, than to those who had 4 or fewer correct answers. Despite the lower range of results in the task assessing visuospatial working memory capacity, a moderate correlation was determined between the two aspects of working memory. Thus, we can assume that lower variability of the results within the task assessing visuospatial working memory could not be the only reason for the lack of correlation with the acquisition level of self-control skills.

Verbal working memory is significant for keeping information related to adapting behavior to social norms (Ponitz, McClelland, Matthews \& Morrison, 2009). Speech is one of the most significant mechanisms of regulating behavior. Correlation between the developmental level of communication skills and realization of life habits was determined in persons with moderate ID (Kaljača \& Dapčević, 2012). By applying a self-instruction strategy, persons with ID become more successful in controlling their own behavior and performing everyday activities (Taylor \& O'Reilly, 1997). Working memory is related to speech development (Määttä, Laakso, Tolvanen, Ahonen \& Aro, 2014). It is possible that verbal aspect of working memory is more significant for selfcontrol in everyday life where a person has a number of social interactions for which verbal communication skills are much more important than visuospatial relations. Within most statements of the Self-Control Rating Scale, a certain form of social interactions is implied, such as keeping promises, following instructions and rules, accepting suggestions, while several items are related to communication act itself.

By reviewing available literature, we did not find any papers which analyzed the relation between different aspects of working memory and self-control in persons with ID. In studies including typically developing persons, most authors considered working memory as a single concept and found correlation between success in tasks assessing working memory and self-control capacity (Hofmann, Schmeichel \& Baddeley, 
2012; Schmeichel, Volokhov \& Demaree, 2008). Persons whose working memory capacity was underdeveloped expressed more pronounced difficulties in focusing their own mental capacities on a task, as well as lower resistance to distracters. The majority of participants with a deficit in working memory domain reported that they had a subjective experience, that their thoughts wandered more often, and that they were not efficient enough since they could not fully focus on the task they had to perform (Kane et al., 2007).

Previous studies determined that the level of self-control in sexual behavior (Khurana et al., 2015), food intake (Houben, Dassen \& Jansen, 2016), and aggressive reactions (Denson et al., 2011) was significantly related to working memory capacity in typically developing persons. Participants with a lower developmental level of working memory capacity were less successful in regulating their own behavior compared to participants whose working memory was better developed (Hofmann, Gschwendner, Friese, Wiers \& Schmitt, 2008). Also, the relation between working memory capacity and reactions to alcohol consumption in risk groups of adolescents (Thush et al., 2008), as well as the relation between working memory capacity and the usage of psychoactive substances (Grenard et al., 2008), were determined.

A group of authors determined that inhibitory control represented the main predictor of acquiring adaptive skills which include work habits, behavior, learning, academic success, and showing symptoms of psychiatric disorders, and that there was no significant correlation between working memory and adaptive skills (Vuontela et al., 2013).

\section{CONCLUSION}

By comparing achievements in working memory tasks and success on Self-Control Rating Scale, it was determined that only verbal aspect of working memory was significantly related to the acquired level of self-control skills, while the 
relation between visuospatial working memory capacity and self-control was not statistically significant in participants with mild ID.

\section{Limitations of the research}

Acquired level of self-control skills was determined by applying a scale, i.e. on the basis of information provided by special educators who were well acquainted with the participants' behavior, while the data on verbal and visuospatial working memory capacity were obtained by direct assessment of participants' behavior while solving the given tasks. A group of authors determined a significant, but low correlation between success in tasks assessing impulsive reactions and the results obtained by applying the scale assessing the ability to control impulsive behavior (Cyders \& Coskunpinar, 2011). It is possible that different assessment methods influenced the obtained results in this research as well.

\section{Implications and recommendations}

Several studies determined that it was possible to improve working memory capacity, and to generalize the effects of working memory training to other domains of cognitive functioning in typically developing children (Holmes, Gathercole \& Dunning, 2009; Klingberg, 2010). The possibility to apply programs for facilitating the development of working memory capacity in persons with mild ID has not been studied enough. It is necessary to assess the effectiveness of verbal working memory training and its influence on selfcontrol capacity in persons with mild ID. 
Specijalna edukacija i rehabilitacija (Beograd), Vol. 16, br. 1. 55-72, 2017.

\section{REFERENCES}

1. Alloway, T. P. (2010). Working memory and executive function profiles of individuals with borderline intellectual functioning. Journal of Intellectual Disability Research, 54(5), 448-456.

2. Alloway, T. P., Gathercole, S. E., \& Pickering, S. J. (2006). Verbal and visuospatial short-term and working memory in children: Are they separable?. Child Development, 77(6), 1698-1716.

3. Baddeley, A. (2012). Working memory: Theories, models, and controversies. Annual Review of Psychology, 63(1), 1-29.

4. Buha, N., \& Gligorović, M. (2012). Povezanost radne memorije i intelektualnog funkcionisanja kod dece sa lakom intelektualnom ometenošću. Specijalna edukacija i rehabilitacija, 11(1), 21-38.

5. Conway, A. R., Kane, M.J., \& Engle, R. W. (2003). Working memory capacity and its relation to general intelligence. Trends in Cognitive Sciences, 7(12), 547-552.

6. Cyders, M. A., \& Coskunpinar, A. (2011). Measurement of constructs using self-report and behavioral lab tasks: Is there overlap in nomothetic span and construct representation for impulsivity?. Clinical Psychology Review, 31(6), 965-982.

7. Dagnan, D., \& Waring, M. (2004). Linking stigma to psychological distress: Testing a social-cognitive model of the experience of people with intellectual disabilities. Clinical Psychology \& Psychotherapy, 11(4), 247-254.

8. Denson, T. F., Capper, M. M., Oaten, M., Friese, M., \& Schofield, T.P. (2011). Self-control training decreases aggression in response to provocation in aggressive individuals. Journal of Research in Personality, 45(2), 252-256.

9. Engle, R. W. (2002). Working memory capacity as executive attention. Current Directions in Psychological Science, 11(1), 19-23.

10. Friso-van den Bos, I., van der Ven, S. H., Kroesbergen, E. H., \& van Luit, J.E. (2013). Working memory and mathematics in primary school children: A meta-analysis. Educational Research Review, 10(1), 29-44. 
Dučić, B.: Relation between working memory and self-control capacity in participants with mild intellectual disability

11. Gathercole, S. E., Alloway, T. P., Willis, C., \& Adams, A. (2006). Working memory in children with reading disabilities. Journal of Experimental Child Psychology, 93(3), 265-281.

12. Grenard, J. L., Ames, S. L., Wiers, R. W., Thush, C., Sussman, S., $\&$ Stacy, A. W. (2008). Working memory capacity moderates the predictive effects of drug-related associations on substance use. Psychology of Addictive Behaviors, 22(3), 426-432.

13. Harrison, L. P., \& Oakland, T. (2003). ABAS II Adaptive Behavior assessment System, 2nd ed. Los Angeles: Western Psychological Services.

14. Hofmann, W., Friese, M., \& Roefs, A. (2009). Three ways to resist temptation: The independent contributions of executive attention, inhibitory control, and affect regulation to the impulse control of eating behavior. Journal of Experimental Social Psychology, 45(2), 431-435.

15. Hofmann, W., Gschwendner, T., Friese, M., Wiers, R. W., \& Schmitt, M. (2008). Working memory capacity and self-regulatory behavior: Toward an individual differences perspective on behavior determination by automatic versus controlled processes. Journal of Personality and Social Psychology, 95(4), 962-977.

16. Hofmann, W., Schmeichel, B. J., \& Baddeley, A. D. (2012). Executive functions and self-regulation. Trends in cognitive sciences, 16(3), 174-180.

17. Holmes, J., Gathercole, S. E., \& Dunning, D. L. (2009). Adaptive training leads to sustained enhancement of poor working memory in children. Developmental Science, 12(4), 9-15.

18. Houben, K., Dassen, F. C., \& Jansen, A. (2016). Taking control: Working memory training in overweight individuals increases self-regulation of food intake. Appetite, 105, 567-574.

19. Kaljača, S., \& Dapčević, D. (2012). Postignuća u oblasti komunikacije i tipovi potrebne podrške kod dece sa umerenom intelektualnom ometenošću. Specijalna edukacija i rehabilitacija, 11(3), 419-434.

20. Kaljača, S., \& Dučić, B. (2016). Odnos veštine samoregulacije i školskog uspeha kod učenika sa lakom i umerenom intelektualnom ometenošću. Specijalna edukacija i rehabilitacija, 15(1), 23-42. 
21. Kane, M. J., Brown, L. H., McVay, J. C., Silvia, P. J., Myin-Germeys, I., \& Kwapil, T. R. (2007). For whom the mind wanders, and when: an experience-sampling study of working memory and executive control in daily life. Psychological Science, 18(7), 614-621.

22. Kane, M. J., Hambrick, D. Z., Tuholski, S. W., Wilhelm, O., Payne, T. W., \& Engle, R. W. (2004). The generality of working memory capacity: A latent-variable approach to verbal and visuospatial memory span and reasoning. Journal of Experimental Psychology: General, 133(2), 189-217.

23. Kendall, P. C., \& Wilcox, L. E. (1979). Self-control in children: Development of a rating scale. Journal of Consulting and Clinical Psychology, 47(6), 1020-1029.

24. Khurana, A., Romer, D., Betancourt, L. M., Brodsky, N. L., Giannetta, J. M., \& Hurt, H. (2015). Stronger working memory reduces sexual risk taking in adolescents, even after controlling for parental influences. Child Development, 86(4), 1125-1141.

25. Klingberg, T. (2010). Training and plasticity of working memory. Trends in Cognitive Sciences, 14(7), 317-324.

26. Määttä, S., Laakso, M. L., Tolvanen, A., Ahonen, T., \& Aro, T. (2014). Children with differing developmental trajectories of prelinguistic communication skills: Language and working memory at age 5. Journal of Speech, Language, and Hearing Research, 57(3), 1026-1039.

27. Pasolunghi, M. C., Cornoldi, C., \& de Liberto, S. (1999). Working memory and intrusions of irrelevant information in a group of specific poor problem solvers. Memory \& Cognition, 27(5), 779790.

28. Pickering, S. (2006). Assessment of working memory in children. In S. Pickering (Ed.), Working memory and education. (pp. 241271). Amsterdam: Elsevier.

29. Ponitz, C. C., McClelland, M. M., Matthews, J. S., \& Morrison, F. J. (2009). A structured observation of behavioral self-regulation and its contribution to kindergarten outcomes. Developmental Psychology, 45(3), 605-619.

30. Schmader, T., \& Johns, M. (2003). Converging evidence that stereotype threat reduces working memory capacity. Journal of Personality and Social Psychology, 85(3), 440-452. 
31. Schmeichel, B. J., Volokhov, R. N., \& Demaree, H. A. (2008). Working memory capacity and the self-regulation of emotional expression and experience. Journal of Personality and Social Psychology, 95(6), 1526-1540.

32. Schuchardt, K., Gebhardt, M., \& Mäehler, C. (2010). Working memory functions in children with different degrees of intellectual disability. Journal of Intellectual Disability Research, 54(4), 346-353.

33. Taylor, I., \& O’Reilly, M. F. (1997). Toward a functional analysis of private verbal self-regulation. Journal of Applied Behavior Analysis, 30(1), 43-58.

34. Thush, C., Wiers, R. W., Ames, S.L., Grenard, J. L., Sussman, S., \& Stacy, A. W. (2008). Interactions between implicit and explicit cognition and working memory capacity in the prediction of alcohol use in at-risk adolescents. Drug and Alcohol Dependence, 94(1-3), 116-124.

35. Vuontela, V., Carlson, S., Troberg, A. M., Fontell, T., Simola, P., Saarinen, S., \& Aronen, E. T. (2013). Working memory, attention, inhibition, and their relation to adaptive functioning and behavioral/emotional symptoms in school-aged children. Child Psychiatry \& Human Development, 44(1), 105-122. 


\title{
ODNOS RADNE MEMORIJE I KAPACITETA SAMOKONTROLE KOD ISPITANIKA SA LAKOM INTELEKTUALNOM OMETENOŠĆU
}

\author{
Bojan Dučić \\ Univerzitet u Beogradu - Fakultet za specijalnu edukaciju i rehabilitaciju
}

\section{Rezime}

Radna memorija se aktivira u situacijama u kojima je potrebno aktivno kontrolisanje usmeravanja pažnje, obrađivanje i kratkoročno održavanje informacija dostupnim. Njen sadržaj je ograničenog kapaciteta i menja se u skladu sa kontekstom u kom se odvija aktivnost. Samokontrola predstavlja kapacitet voljnog svesnog napora da se istraje u realizaciji unapred postavljenog cilja.

Cilj istraživanja je da se utvrdi odnos verbalnog i vizuospacijalnog aspekta radne memorije i veština samokontrole kod osoba sa lakom intelektualnom ometenošću (IO).

Uzorkom je obuhvaćeno 40 ispitanika uzrasta od 8 do 12 godina (AS=10,65, SD=1,19).

Zadatak Pamćenje lavirinta, prilagođen za ispitanike sa IO, upotrebljen je da bi se utvrdio kapacitet vizuospacijalnog aspekta radne memorije. Za procenu verbalnog aspekta radne memorije upotrebljen je zadatak Pamćenje životinja, a nivo usvojenosti veština samokontrole ispitan je primenom Skale za procenu samokontrole.

Utvrđeno je da je verbalni aspekt radne memorije značajno povezan sa nivoom usvojenosti veština samokontrole $(\mathrm{p}=0,002)$. Rezultati na zadatku za procenu kapaciteta vizuospacijalne radne memorije i uspeh na skali za procenu kapaciteta samokontrole nisu bili značajno povezani $(\mathrm{p}=0,089)$.

Povezanost samokontrole sa verbalnim aspektom radne memorije može se tumačiti bliskim vezama upotrebe govora u primeni strategija za regulaciju sopstvenog ponašanja.

Ključne reči: radna memorija, samokontrola, intelektualna ometenost

Primljeno: 08.12.2016.

Prihvaćeno: 23.01.2017. 